\title{
Analysis of Consumer Satisfaction and Loyalty Factors with CRM Approach in Agribusiness E-commerce Company
}

\author{
Iqra Rizky Goranda ${ }^{1 *)}$, Popong Nurhayati², Megawati Simanjuntak ${ }^{3}$ \\ ${ }^{1,2}$ School of Business, IPB University, Bogor 16151, Indonesia \\ ${ }^{3}$ Department of Family and Consumers Science, Faculty of Human Ecology, IPB \\ University, Darmaga, Bogor 16680, Indonesia \\ *Corresponding author: iqrarizky2195@gmail.com
}

\begin{abstract}
$\mathrm{XYZ}$ e-commerce is a company that sells an agricultural product that draws benefits from the COVID-19 pandemic. The purpose of this research was to analyze CRM factors, satisfaction, and consumer loyalty. This study using quantitative research selected with convenience sampling. The online survey applied toward 232 respondents who were unsatisfied with the service in Jabodetabek and processed using Structural Equation Model (SEM). Based on the SEM results, it was found that CRM has a significant effect on consumer satisfaction and consumer satisfaction with consumer loyalty. In contrast, CRM has no significant effect on consumer loyalty. This research concluded that XYZ needs to become a company that makes it easy for consumers, is professional, reliable and trustworthy. However, efforts need to be made to improve the relationship between criticism and suggestions, communication and providing information, regulating product availability, delivery time, and saving consumer costs - the results of this research results are expected to increase satisfaction and loyalty through the CRM approach.
\end{abstract}

Keywords: consumer loyalty, consumer satisfaction, customer relationship management (CRM), structural equation model (SEM)

\begin{abstract}
Abstrak
XYZ e-commerce adalah perusahaan yang bergerak menjual produk pertanian yang diuntungkan dengan adanya pandemi COVID-19. Tujuan dari penelitian ini adalah untuk menganalisis faktor CRM, kepuasan, dan loyalitas konsumen. Studi ini menggunakan riset kuantitatif menggunakan dan dipilih dengan convenience sampling. Data didapatkan dengan menggunakan online survei dan mendapatkan 232 responden yang tidak puas dengan jasa di Jabodetabek dan diolah lanut dengan Structural Equation Model (SEM). Berdasarkan hasil SEM diketahui bahwa CRM berpengaruh signifikan terhadap kepuasan konsumen dan kepuasan konsumen terhadap loyalitas konsumen. Sebaliknya, CRM tidak berpengaruh signifikan terhadap loyalitas konsumen. Implikasi manajerial pada penelitian ini adalah XYZ harus menjadi perusahaan yang memudahkan konsumen, profesional, dapat diandalkan dan dipercaya. Namun ada yang harus diperbaiki dari aspek hubungan kritik dan saran, komunikasi dan pemberian informasi, mengatur kesediaan produk, waktu pengiriman dan dapat menghemat biaya kosnumen. Hasil penelitian ini diharapkan dapat meningkatkan kepuasan dan loyalitas melalui pendekatan CRM.
\end{abstract}

Kata kunci: kepuasan komsumen, loyalitas konsumen, manajemen hubungan pelanggan (CRM), model persamaan hubungan (SEM) 


\section{Introduction}

COVID-19 is a disease that causes activities such as traditional markets to become vulnerable. This activity's delay is due to government policies of restrictions on the social scale (PSBB). As a result, traditional markets become eluded public places. According to BPS (2020), it can be seen that traditional markets are the lowest in areas of implementation of health protocols. Since April 2020, there was $46 \%$ in grocery spending, particularly in online shopping. PT XYZ's e-commerce also feels this development.

The business world has also begun to change its goal from production-oriented to customer-oriented. The characteristic of customer-oriented is to prioritise the value provided by the company against its products. Companies must show their consumers that the value specified, quality of service, price, promotion, and trust are the ones desired by consumers. Therefore, it makes an excellent profound marketing approach to build relationships between consumers and companies, namely Customer Relationship Management (CRM). Customer relationship management (CRM) is a marketing approach taken by retaining old customers and finding new customers. Relationship upkeep helps build long-term and profitable customer relationships (Dawes, 2009; Buttle, 2007). This is also reinforced by Soliman (2011), which mentioned CRM is a critical approach because nearly $60 \%$ of businesses need CRM. This CRM approach makes it easier for companies to make transactions faster and helps in increasing satisfaction and then increasing consumer loyalty.

A study conducted by Hassan, Nawaz, Lashari, and Zafar (2014) that customer relationship management has a significant effect on the consumer's positive relation. It will the company's sales level cause the increase in organisational profit. This is because the number of loyal consumers will increase. The same conclusion with research conducted by Emaluta, Isnalita, and Soewarno (2019) indicates that CRM directly affects consumer loyalty through consumer satisfaction. E-commerce XYZ is one of the pioneers of e-commerce engaged in agribusiness in the sale of foodstuffs. This ecommerce was founded in 2016 and is moving due to concerns over tiny farmers' selling prices and too long trade routes. XYZ e-commerce stands to overcome these concerns and make agribusiness distribution better. XYZ e-commerce also knows that the relationship between companies and consumers is also significant.

The pre-research results showed the distrust of agribusiness e-commerce attains $70 \%$ of consumers complained. The complaints covered the services provided, including delivery unreachable, defective or unavailable items, late delivery, minimum shopping requirements, a higher price than the market price, and an error in the XYZ ecommerce application. Based on the data above, there are $30 \%$ of respondents feel dissatisfied. Dissatisfaction and distrust are still the problems of XYZ's e-commerce. Pre-research also in the pandemic phase shows an increase in the number of new users by $64 \%$, with the duration of application usage still under three months. Due to the "new normal" during the pandemic, there was increasing application usage, forcing consumers to switch from offline to online purchases. The increasing of new users is an opportunity for XYZ's e-commerce as a second-leading agribusiness application. According to data also, the respondents feel dissatisfied it can be said that low. So, if this dissatisfied respondent feels otherwise, XYZ e-commerce can grab the whole market share. 

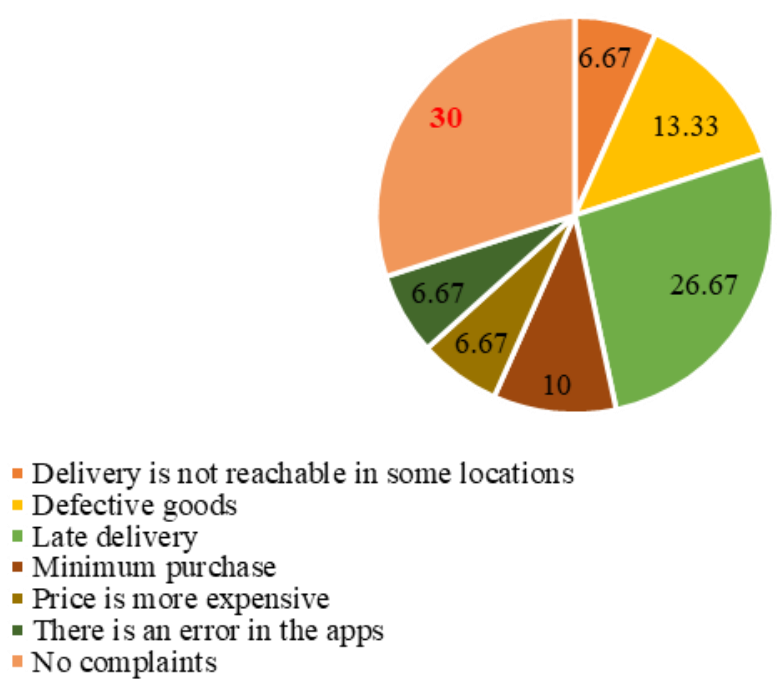

Figure 1 Types of XYZ e-commerce consumer complaints

One of the solutions for dissatisfaction is CRM. CRM strategy is a marketing strategy right to solve the problem. A successful CRM implementation can pay off many benefits for the company (Brenski, 2015). The main advantage of CRM was reducing costs, intellectual property, product customisation, sales forecasting, brand equity, and profits. The brand increasing is noticeable by the number of consumers who feel satisfied, loyal, and recommend the company brand. A good CRM strategy will increase purchase interest, reaction to favourable prices, brand development, and preference for the brands purchased (Ghazian, Hossaini \& Farsijani, 2016). The urgency of this research is mainly due to the increasing using the application. How to ecommerce XYZ can be increasing satisfaction and eventually can grab trust from audiences.

Based on the above phenomenon and previous studies, CRM can affect consumer satisfaction and loyalty. This makes research aimed at (1) identify what factors can make audiences satisfaction dan loyalty of e-commerce XYZ, (2) analyze the relationship between the characteristics of the audience with satisfaction, (3) analyze the relationship between the variables and 4) Give an implication managerial that can be used for XYZ e-commerce agribusiness.

The contribution to knowledge that is expected to be obtained is (1) evaluation and improvement for the company and investigate the relationship between CRM, consumer satisfaction, and loyalty for e-commerce consumers $\mathrm{XYZ}$ is not satisfied. Furthermore, (2) become a reference for the researcher who will conduct studies in consumer behaviour, especially in customer relationship management, consumer satisfaction and consumer loyalty. This research was quite different from the previous research regarding the research object that focused on agribusiness e-commerce. 


\section{Literature Review}

\section{Customer Relationship Management (CRM)}

CRM is the most crucial concept in modern marketing. The definition of CRM is a building process and build relationships with customers in creating value and satisfaction (Kotler and Keller, 2016). There are four factors in CRM success, namely human resources, process, technology, and knowledge (Gordon, 2002). Darvish, Kafashzadeh, and Ahmadnia (2012) defined that CRM as a consumer-focused managerial strategy that builds long-term profitable customer relationships. CRM strategy, including marketing, operations, sales, customer services, human resources, finance, and information technology, and CRM implementation is customer-centric (Vasiliu, 2012).

According to Rahayu, Kifti, Informasi, and Royal (2018), managing CRM properly is important because CRM is one way to maintain customer loyalty with a certain brand or product. In the concept of CRM, there are several phases. These phases are acquisition, enhancement and retention. The acquisition is an activity to offer various products tailored to consumers' needs or desires, offering the product on consumer experiences and providing the best services to create consumer satisfaction. Enhancement is the form of activities carried out to increase product sales, sales to customers, and prospective customers. Finally, retention is used to obtain customer information and provide product offerings (Dewa \& Setyohadi, 2017).

Khedkar conducts some research (2015) that mentioned that an effective CRM would lead to consumer satisfaction. If consumers are satisfied, it will lead to decent word of mouth and loyalty, thus making business superior and creating increased profits and income. Moreover, Victor, Rotinsulu, and Jacky (2015) showed a significant relationship with consumer satisfaction. CRM also significantly impacts CRM toward consumer loyalty (Setyaleksana, Suharyono \& Yulianto, 2017). For some of that explanation, it concluded that CRM is a marketing strategy that aims a good relationship between the company and its customers to easily explore information about customers needed and maximise that to increase customer satisfaction and eventually affect customer loyalty.

\section{Consumer Satisfaction}

Consumer satisfaction is a feeling of pleasure to disappointment from comparing a brand's service, product, or performance. Satisfaction is sensed when services, products, or performance has exceeded consumer expectations (Kotler and Keller, 2016). It can also result from consumers feeling about company performance in meeting customer expectations, and customers can feel that their expectations are fulfilled (Soegoto, 2013). Customers are expected to get 4C's of satisfaction, namely customer needs, convenience, cost and communication, and hope to become loyal. The higher the level of customer satisfaction, the higher customer loyalty.

Customer satisfaction can be achieved through CRM. According to Supar, Suasana, and Ketut (2017), CRM is focused on long-term and sustainable relationships that can positively impact consumer satisfaction. In addition, Lestari and Suwitho (2018) said that consumers satisfaction could not be separated from the relationship between the expectation received. According to Smith and Chang (2010), consumer 
satisfaction indicators are product quality, service quality, product innovation, and brand image.

There is some research conducted by Setyaleksana et al. (2017) noted that consumer satisfaction had a significant and positive influence, and then satisfaction would lead to loyalty (Khedar, 2015). For some of that explanation concluded that consumer satisfaction is the feeling of consumers expectation is fulfilled. CRM is one way to fulfil that expectation by looking at consumers' demands, customising that with data, and creating satisfaction.

\section{Consumer Loyalty}

Consumer loyalty is the level of consumer loyalty toward goods or services to consume or purchase regularly and becomes a habit binding (Engel, Blackwell \& Miniard, 1994). The characteristics of loyal consumers are rejecting goods or services from other brands, making repeat purchases, buying products of the same brand, and recommending products or services to others (Griffin, 2003).

Consumer loyalty is very important to the company because loyalty can maintain the survival of the product or services. Loyal consumers have enthusiasts recommend to anyone they know to use certain products or services (Yuliana, 2018). Iriandi and Yulianto, and Mawardi (2015) conduct some research, found a significant relationship between consumer satisfaction and loyalty. This was also illustrious by Khedar (2015). Therefore, consumer loyalty can be influence by several factors, including consumer satisfaction and one-way to get to that by using customer relationship management.

Based on previous empirical research that has been previously described, it has been found that there is a relationship between CRM, consumer satisfaction and loyalty. This model's difference from the previous model is the dimension used in these variables, mainly consumer experience through online buying. This research is different from others because if we discuss CRM mainly for services, such as banking. This description above can describe the framework of CRM, consumer satisfaction and loyalty as presented in Figure 2.

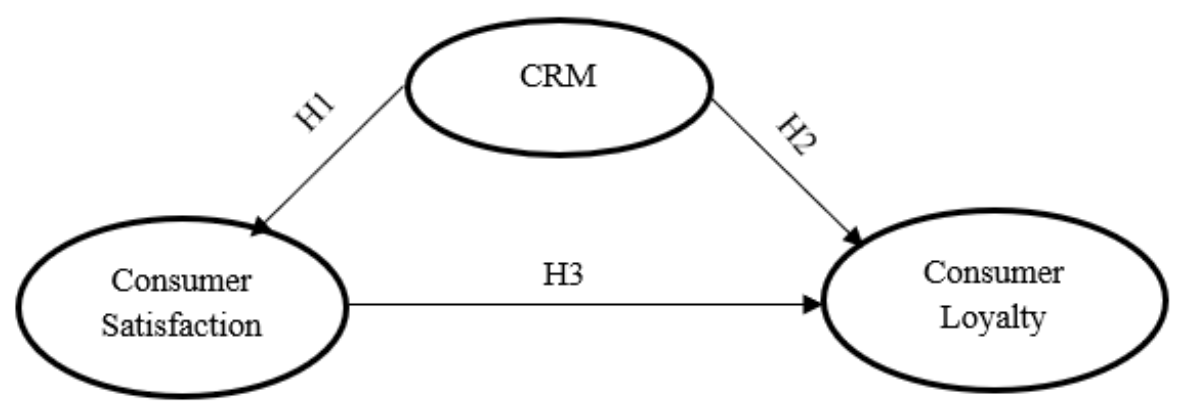

Figure 2 Conceptual model

The hypotheses research of this study can be concluded as follows:

H1: CRM has a direct and positive effect on consumer satisfaction

H2: CRM has a direct and positive effect on consumer loyalty

H3: Consumer satisfaction has a direct and positive effect on consumer loyalty 


\section{Methods}

\section{Participants}

This study applied a quantitative approach to analyze CRM factors, consumer satisfaction, and consumer loyalty. The sampling technique conveyed convenience sampling as part of the non-probability sampling technique. This sampling technique is done by choosing the easiest to provide the information needed and filling out a questionnaire. It choose $\mathrm{XYZ}$ as sample because $\mathrm{XYZ}$ is more popular and increased the number of users during this pandemic. The number of samples that met the criteria was 232 respondents out of 414 respondents. The criteria were consumers that bought at least once on XYZ e-commerce, were 17 years old and experiencing dissatisfaction. The data was collected through an online survey using Google Forms by sharing the questionnaire link through advertising on Facebook and Google.

\section{Measurement}

The questionnaire in this study consisted of people, processes, technology and knowledge for the variables of customer relationship management. The Cronbach's Alpha value of this instrument was 0.6. There are four dimensions for satisfaction: quality of product, service quality, innovative product, and brand image. The Cronbach's Alpha value of this instrument was 0.6. These four dimensions are also for loyalty consumers who are refuse, repeat purchase, reward and recommendation. The Cronbach's Alpha value of this instrument was 0.6.

The Likert scale was applied for indicators with four-point of 1 (strongly disagree), 2 (disagree), 3 (agree), and 4 (strongly agree) (Sumarwan, Hartoyo \& Fahmi, 2018). Before distributing the questionnaire, the validity and reliability were tested. There are two kinds of variables used in this study, namely the dependent variables, such as consumer satisfaction (Y1) and consumer loyalty (Y2), and the independent variable, namely $\mathrm{CRM}(\mathrm{X})$. In this study, each variable has four dimensions. Following is an explanation of the variables and dimensions in this study shown in Table 1.

Table 1 Variables and indicators

\begin{tabular}{|c|c|c|c|c|}
\hline $\begin{array}{l}\text { Latent } \\
\text { variable }\end{array}$ & $\begin{array}{l}\text { Definition } \\
\text { Operational }\end{array}$ & $\begin{array}{l}\text { Dimensions } \\
\text { (Symbol) }\end{array}$ & Definition Operational & $\begin{array}{l}\text { Indicators Variables } \\
\text { (Symbol) }\end{array}$ \\
\hline $\begin{array}{l}\text { Customer } \\
\text { Relationship } \\
\text { Management }\end{array}$ & $\begin{array}{l}\text { Process } \\
\text { build and } \\
\text { weave }\end{array}$ & $\begin{array}{l}\text { People } \\
\text { CRM1 }\end{array}$ & $\begin{array}{l}\text { Human is managing } \\
\text { relationships so it is } \\
\text { needed personal touch }\end{array}$ & $\begin{array}{l}\text { Professional (CRM11) } \\
\text { Response (CRM12) } \\
\text { Keep the relationship } \\
\text { (CRM13) }\end{array}$ \\
\hline $\begin{array}{l}\text { (Kotler \& } \\
\text { Keller, } \\
2016), \\
\text { (Gordon, } \\
2002)\end{array}$ & $\begin{array}{l}\text { relationship } \\
\text { with } \\
\text { customer in } \\
\text { create score } \\
\text { and } \\
\text { satisfaction }\end{array}$ & $\begin{array}{l}\text { Process } \\
\text { CRM2 }\end{array}$ & $\begin{array}{l}\text { Process is system or } \\
\text { that procedure done so } \\
\text { that relationship among } \\
\text { consumer and } \\
\text { companies are getting } \\
\text { close and wide awake }\end{array}$ & $\begin{array}{l}\text { Relations criticism and } \\
\text { suggestion (CRM21) } \\
\text { Notice willingness product } \\
\text { (CRM22) } \\
\text { Service easy (CRM23) } \\
\text { Service fast (CRM24) }\end{array}$ \\
\hline
\end{tabular}


Table 1 Variables dan indicators (Continued..)

\begin{tabular}{|c|c|c|c|c|}
\hline $\begin{array}{l}\text { Latent } \\
\text { variable }\end{array}$ & $\begin{array}{l}\text { Definition } \\
\text { Operational }\end{array}$ & $\begin{array}{l}\text { Dimensions } \\
\text { (Symbol) }\end{array}$ & $\begin{array}{l}\text { Definition } \\
\text { Operational }\end{array}$ & $\begin{array}{l}\text { Indicators Variables } \\
\text { (Symbol) }\end{array}$ \\
\hline \multirow{2}{*}{$\begin{array}{l}\text { Customer } \\
\text { Relationship } \\
\text { Management } \\
\text { (CRM) } \\
\text { (Kotler \& } \\
\text { Keller, 2016), } \\
\text { (Gordon, 2002) }\end{array}$} & \multirow{2}{*}{$\begin{array}{l}\text { Process } \\
\text { build and } \\
\text { weave } \\
\text { relationship } \\
\text { with } \\
\text { customer in } \\
\text { create score } \\
\text { and } \\
\text { satisfaction }\end{array}$} & $\begin{array}{l}\text { Technology } \\
\text { CRM3 }\end{array}$ & $\begin{array}{l}\text { Technology used } \\
\text { for speed up and } \\
\text { optimising process } \\
\text { factors and man } \\
\text { on CRM activity }\end{array}$ & $\begin{array}{l}\text { Application make it easier } \\
\text { purchase (CRM31) } \\
\text { Application corresponding } \\
\text { needs (CRM32) } \\
\text { Display application } \\
\text { (CRM33) } \\
\text { Application make it easier } \\
\text { access information } \\
\text { (CRM34) }\end{array}$ \\
\hline & & $\begin{array}{l}\text { Knowledge } \\
\text { CRM4 }\end{array}$ & $\begin{array}{l}\text { Understanding the } \\
\text { right one will } \\
\text { CRM program can } \\
\text { be applied } \\
\text { with good so that } \\
\text { goal destination } \\
\text { company easy for } \\
\text { achieved. }\end{array}$ & $\begin{array}{l}\text { Have product knowledge } \\
\text { (CRM41) } \\
\text { Use database (CRM42) } \\
\text { Engaging consumers } \\
\text { (CRM43) } \\
\text { Provide solutions } \\
\text { (CRM44) Communication } \\
\text { and providing information } \\
\text { (CRM45) }\end{array}$ \\
\hline \multirow[b]{2}{*}{$\begin{array}{l}\text { Customer } \\
\text { Satisfaction } \\
(\mathrm{KK}) \\
\text { (Smith \& } \\
\text { Chang, 2010) }\end{array}$} & \multirow[b]{2}{*}{$\begin{array}{l}\text { Evaluation } \\
\text { consumer to } \\
\text { product or } \\
\text { deep } \\
\text { services, } \\
\text { fulfill needs } \\
\text { and desire } \\
\text { consumer }\end{array}$} & $\begin{array}{l}\text { Quality } \\
\text { Product } \\
\text { KK1 }\end{array}$ & $\begin{array}{l}\text { product quality is } \\
\text { ability a product } \\
\text { to show various } \\
\text { functions } \\
\text { including } \\
\text { endurance, } \\
\text { reliability, } \\
\text { accuracy and } \\
\text { convenience in } \\
\text { usage }\end{array}$ & $\begin{array}{l}\text { Overall satisfied (KK11) } \\
\text { Top quality (KK12) } \\
\text { Always available (KK13) } \\
\text { Lots its kind } \\
\text { (KK14) } \\
\text { I did fulfil consumer desires } \\
\text { (KK15) }\end{array}$ \\
\hline & & $\begin{array}{l}\text { Quality } \\
\text { service } \\
\text { KK2 } \\
\text { Innovation } \\
\text { product } \\
\text { KK3 }\end{array}$ & $\begin{array}{l}\text { Service quality the } \\
\text { good is not just } \\
\text { answer consumer } \\
\text { complaints but } \\
\text { also can solve } \\
\text { problem will } \\
\text { needs or desire is } \\
\text { there after buy } \\
\text { products or } \\
\text { service Innovation } \\
\text { product is used } \\
\text { by company to } \\
\text { create new uses } \\
\text { has a function } \\
\text { additional or } \\
\text { novelty }\end{array}$ & $\begin{array}{l}\text { Overall satisfied (KK21) } \\
\text { Best service } \\
\text { (KK22) } \\
\text { Delivery time } \\
\text { (KK23) } \\
\text { Packaged with good (KK24) } \\
\text { Useful promos } \\
\text { (KK25) } \\
\text { Saving time consumer } \\
\text { (KK26) } \\
\text { Save cost shop (KK27) } \\
\text { Corresponding with the } \\
\text { needs of the times present } \\
\text { (KK31) } \\
\text { e-commerce first that used } \\
\text { (KK32) } \\
\text { Very effective in distribution } \\
\text { (KK33) } \\
\text { Payment options various } \\
\text { sorts (KK34) } \\
\text { Easy payment } \\
\text { (KK35) }\end{array}$ \\
\hline
\end{tabular}


Table 1. Variables dan Indicators (continued...)

\begin{tabular}{|c|c|c|c|c|}
\hline Latent variable & $\begin{array}{l}\text { Definition } \\
\text { Operational }\end{array}$ & $\begin{array}{l}\text { Dimensions } \\
(\text { Symbol })\end{array}$ & $\begin{array}{l}\text { Definition } \\
\text { Operational }\end{array}$ & $\begin{array}{l}\text { Indicators } \\
\text { (Symbol) }\end{array}$ \\
\hline $\begin{array}{l}\text { Customer } \\
\text { Satisfaction } \\
(\mathrm{KK}) \\
\text { (Smith \& } \\
\text { Chang, 2010) }\end{array}$ & $\begin{array}{l}\text { Evaluation } \\
\text { consumer to } \\
\text { product or deep } \\
\text { services, fulfill } \\
\text { needs and desire } \\
\text { consumer }\end{array}$ & $\begin{array}{l}\text { Brand } \\
\text { Image } \\
\text { KK4 }\end{array}$ & $\begin{array}{l}\text { brand image is the } \\
\text { response from } \\
\text { consumers against } \\
\text { brand, mark or } \\
\text { perception from } \\
\text { belongs to from } \\
\text { individual to } \\
\text { products } \\
\text { services. }\end{array}$ & $\begin{array}{l}\text { Using } \\
\text { e-commerce XYZ in } \\
\text { buying online (KK41) } \\
\text { Easy transaction and safe } \\
\text { (KK42) } \\
\text { Reliable (KK43) } \\
\text { Could trusted (KK44) } \\
\text { Company image good } \\
\text { (KK45) } \\
\text { Provide value add (KK46) } \\
\text { Cost shop lower (KK47) }\end{array}$ \\
\hline \multirow{4}{*}{$\begin{array}{l}\text { Loyalty } \\
\text { Consumer (LK) } \\
\text { (Griffin, 2003) }\end{array}$} & \multirow{4}{*}{$\begin{array}{l}\text { Loyalty is } \\
\text { level of loyalty } \\
\text { consumer } \\
\text { with } \\
\text { consume } \\
\text { or do } \\
\text { purchase } \\
\text { repeatedly } \\
\text { continously } \\
\text { and become } \\
\text { habit } \\
\text { (Engel et al. } \\
\text { 1994) }\end{array}$} & $\begin{array}{l}\text { Refuse } \\
\text { LK1 }\end{array}$ & $\begin{array}{l}\text { Show immunity } \\
\text { from the lure a } \\
\text { kind of competitor }\end{array}$ & $\begin{array}{l}\text { Not interested in } \\
\text { competitors (LK11) } \\
\text { Continue becomes } \\
\text { consumer (LK12) } \\
\text { It won't matter with that } \\
\text { offered by competitors } \\
\text { (LK13) }\end{array}$ \\
\hline & & $\begin{array}{l}\text { Repeat } \\
\text { Purchases } \\
\text { LK2 }\end{array}$ & $\begin{array}{l}\text { To do purchase } \\
\text { online regular }\end{array}$ & $\begin{array}{l}\text { Buy more than one } \\
\text { times (LK21) } \\
\text { Buy without promotion } \\
\text { (LK22) } \\
\text { Buy because quality } \\
\text { (LK23) } \\
\text { Buy because } \\
\text { service (LK24) } \\
\text { Buy because innovation } \\
\text { (LK25) }\end{array}$ \\
\hline & & $\begin{array}{l}\text { Reward } \\
\text { LK3 }\end{array}$ & $\begin{array}{l}\text { Buy a product or } \\
\text { interline services }\end{array}$ & $\begin{array}{l}\text { Can buy more than one } \\
\text { product (LK31) } \\
\text { Like the promo } \\
\text { (LK32) } \\
\text { Rewards that make I } \\
\text { switched (LK33) }\end{array}$ \\
\hline & & $\begin{array}{l}\text { Recommend } \\
\text { ation } \\
\text { LK4 }\end{array}$ & $\begin{array}{l}\text { Referencing } \\
\text { product to other } \\
\text { people }\end{array}$ & $\begin{array}{l}\text { Recommending e- } \\
\text { commerce XYZ (LK41) } \\
\text { Telling experience (LK42) } \\
\text { Telling positive thing } \\
\text { (LK43) }\end{array}$ \\
\hline
\end{tabular}

\section{Analysis}

The analysis applied in this study was Structural Equation Models (SEM) with LISREL 8.80. SEM analysis aimed to examine the relationship between variables. The two steps in this analysis assess the measurement model and the structural model (Hair, Black, Babin \& Anderson, 2010). The measurement model was conducted to assess the reliability and validity of the model. If the loading factor value is $\geq 0.5$, the model can be concluded to be valid. In contrast, for measurement reliability, if the construct reliability value is $\geq 0.7$ and the Average Variance Extracted (AVE) value is $\geq 0.5$, it is alleged that the model is reliable (Hair et al., 2010). After the measurement model, the structural model measures several parameters such as chi-square, RMSEA, NFI, CFI, RMR, RFI, GFI, and AGFI. 


\section{Respondent Characteristics}

\section{Findings}

Among 232 respondents, most of them are female (93.10\%), married (73.28\%), and between 31 to 40 years $(68.53 \%)$. The majority of respondents hold a bachelor's degree (S1) (81.47\%). Their professions consecutively were private employees (43.97\%), housewives (15.52\%), and entrepreneurs (11.21\%). Most respondents stay in Jakarta $(41.38 \%)$ with more than three million rupiahs of income and expenses. The frequency of purchases is between 3 to 5 times and less than three times per month. The average money spending to purchase is between Rp. 100.000 to Rp. 349.000 (58.62\%). The most frequent products they bought are vegetables (43.10\%).

\section{Satisfaction Level Based on Consumer Characteristics}

Based on Table 2, age, occupation, income, and domicile had a significant relationship with consumer satisfaction. For example, respondents more than $\geq 30$ years of age have a job, have an income of $\geq$ Rp 2.000.000 and stay in Jakarta satisfied with $\mathrm{XYZ}$ e-commerce. This is because consumers with the above criteria are busy with their work and economy. It means, XYZ e-commerce is the right solution for consumer problems, and they feel helped by XYZ e-commerce.

Table 2 Cross-tabulation between respondent characteristics and level of satisfaction

\begin{tabular}{llccc}
\hline \multirow{2}{*}{ Characteristics } & Category & \multicolumn{2}{c}{ Percentage (\%) } & \multirow{2}{*}{$\begin{array}{c}\text { Asymp. sig } \\
\text { (2-sided) }\end{array}$} \\
\cline { 3 - 4 } Gender & Male & Not satisfied & Satisfied & 0.220 \\
\multirow{2}{*}{ Age } & Female & 2.01 & 3.87 & \\
\multirow{3}{*}{ Level of education } & Intermediate & 1.15 & 65.94 & $0.000^{*}$ \\
& High & 20.68 & 9.91 & \\
\multirow{2}{*}{ Profession } & Hnears & 28.87 & 59.91 & 0.566 \\
& Employed & 11.63 & 28.87 & \\
\multirow{2}{*}{ Income } & 18.53 & 65.51 & $0.002^{*}$ \\
& Rpp & 8.62 & 56.46 & \\
\multirow{2}{*}{ Domicile } & 2.000.000 & & 3.44 & $0.000^{*}$ \\
& Rp & 21.55 & 66.37 & \\
& 2.000 .000 & 15.08 & 25.00 & $0.043^{*}$ \\
\hline
\end{tabular}

Note: * significant if the asymp.sig value $<0.05$

Furthermore, gender and education level did not significantly correlate with the satisfaction of XYZ e-commerce. This is because all gender and level of education can use e-commerce. The ability of consumers to use e-commerce applications and websites $\mathrm{XYZ}$ is not relevant for comparing the satisfaction level. Moreover, the ease of learning something can already be obtained easily. XYZ can do it by providing a tutorial on how to use the application. Therefore, XYZ e-commerce must consider other variables for applying the marketing strategy. 


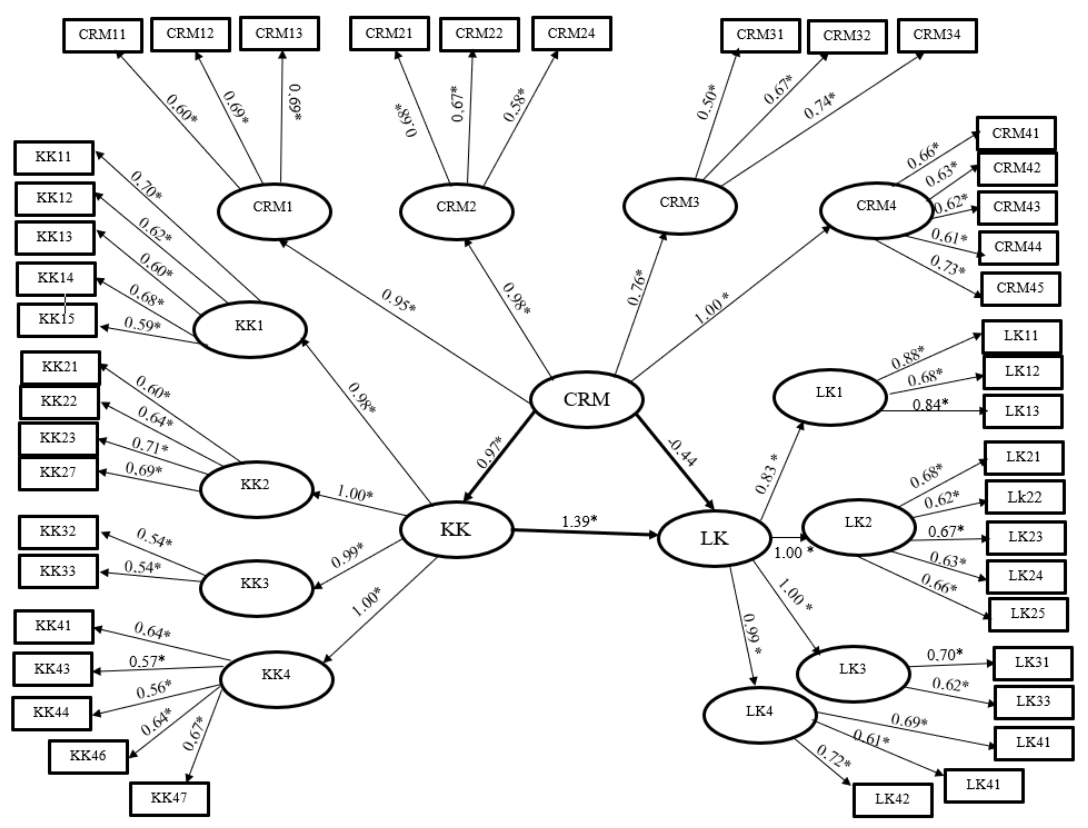

Figure 3 The result of the validity test

Table 3 Result of the latent construct reliability test

\begin{tabular}{lllc}
\hline Variables & \multicolumn{1}{c}{ Dimensions } & AVE & CR \\
\hline Customer relationship management & People, Process, Technology, Knowledge & 0.5 & 0.9 \\
Consumer satisfaction & $\begin{array}{l}\text { Quality product, Quality service, Innovation product, } \\
\text { Brand image }\end{array}$ & 0.5 & 0.9 \\
Consumer loyalty & Refuse, Repeat purchases, Reward, Recommendation & 0.5 & 0.9 \\
\hline
\end{tabular}

From the validity test, twelve indicators were issued from 54 existing indicators. After eliminated twelve invalid indicators, Figure 3 shows valid indicators. AVE and CR values have also been met so that the reliable variables (Table 3 ), so the measurement model has been fulfilled and can proceed for structural testing and hypothesis testing.

\section{Structural Model}

Structural models were designed for viewing estimates to validate the conceptual model. The goodness-of-fit result is the first tool before testing, and the results are shown in Table 4. Based on the goodness-of-fit test results, it was found that the model suggested at the beginning was a good fit and appropriate to proceed to hypothesis testing. 
Table 4 Goodness-of-fit result for overall model fit

\begin{tabular}{lccc}
\hline The goodness of Fit Parameters & Cut-off value & Result & Conclusions \\
\hline Chi-square & The smaller, the better & 1857,71 & Good fit \\
RMSEA & $\leq 0.08$ & 0,068 & Good fit \\
NFI & $\geq 0.90$ & 0.95 & Good fit \\
CFI & $\geq 0.90$ & 0.97 & Good fit \\
IFI (Incremental Fit Index) & $\geq 0.90$ & 0.97 & Good fit \\
RMR (Root Mean Square Residual) & $\leq 0.05$ & 0.030 & Good fit \\
RFI (Relative Fit Index) & $\geq 0.95$ & 0.94 & Good fit \\
GFI (Good Fit Index) & $\geq 0.90$ & 0.73 & Bad fit \\
AGFI (Adjusted Good Fit Index) & $\geq 0.90$ & 0.70 & Bad fit \\
\hline
\end{tabular}

\section{Contribution of Indicators to Latent Variables}

Each indicator contributes differently to showing latent dimensions and variables. The greater the loading factor of an indicator, the greater the contribution of the indicator in explaining the latent variable. The required loading factor is more than 0.5 , so indicators that have a value below 0.5 need to be eliminated from the analysis model so that the loading factor meets the validity test requirements. In this analysis of this model there two indicators were eliminated from CRM variable, namely CRM23 ("the easiness of service") and CRM33 ("user interface of application"). Eight indicators were eliminated from consumer satisfaction variable, namely KK24 ("wrap up very well"), KK25 ("benefit of promo"), KK26 ("saving consumer time"), KK31 ("the need of this era"), KK34 ("many choices"), KK35 ("easy payment"), KK42 ("transaction easy and secure"), KK45 ("good brand image") and one indicator was eliminated from consumers loyalty variable namely LK32 ("liking the promo").

Customer relationship management consists of 4 dimensions, namely people, process, technology, and knowledge. The biggest indicator describing the CRM variable was CRM34 ("company makes it easy to access information"), with a loading factor of 0.74. It means that this indicator can explain CRM variable 74\%. On the contrary, CRM31 was the weakest to explain CRM variable with loading factors 0.50 .

Consumer satisfaction consists of 4 dimensions: quality of product, quality of services, product innovation, and brand image. The biggest indicator describing the consumer satisfaction variable was KK23 ("delivering time"), with a loading factor of 0.71. It means that this indicator can explain the consumer satisfaction variable $71 \%$. On the contrary, KK32 and KK33 were the weakest to explain consumer satisfaction variables with loading factors 0.54 .

Consumer loyalty consists of 4 dimensions, namely refuse, repeat purchases, reward, and recommendation. The biggest indicator describing the consumer loyalty variable was LK11 ("not interest with competitors"), with a loading factor of 0.88 . It means that this indicator can explain the consumer loyalty variable $88 \%$. On the contrary, LK33 was the weakest to explain CRM variable with loading factors 0.56 .

\section{Hypothesis Testing}

The result of hypothesis testing can be seen in Table 5. The hypothesis testing found that CRM significantly influenced consumer satisfaction (0.97) and consumer satisfaction had a significant effect on consumer loyalty (1.39); meanwhile, the CRM variable on consumer loyalty (-0.44) shows an insignificant impact. The indirect effect 
was obtained from the CRM variable's path on consumer satisfaction and then consumer loyalty. This condition is in line with the conditions in the field for CRM to consumer satisfaction, and e-commerce XYZ builds an application and website for accessible information and they also launching virtual assistance, which makes service is good. $\mathrm{XYZ}$ gives a top-quality product that exceeds consumer expectations for consumer satisfaction to consumer loyalty in line with the field. However, the relationship between CRM and consumer loyalty is insignificant because consumers are still new to the new behaviour, which is buying something to application and consumer does not want to do something new.

Table 4 Hypothesis testing

\begin{tabular}{lccr}
\hline Paths & Path Coefficient & $\boldsymbol{t}$-value & Conclusion \\
\hline CRM $\rightarrow$ Consumer satisfaction & 0.97 & 5.55 & Significant \\
CRM $\rightarrow$ Consumer loyalty & -0.44 & 0.49 & Insignificant \\
Consumer satisfaction $\rightarrow$ Consumer loyalty & 1.39 & 2.65 & Significant \\
\hline
\end{tabular}

\section{Discussion}

This study aimed to determine what factors can make audiences satisfaction and loyalty of e-commerce XYZ, analyze the relationship between the characteristics of the audience with satisfaction, analyze the relationship between the variables, and give an implication managerial that can be used for XYZ e-commerce agribusiness.

Based on respondent characteristics, all users are women, and their age fell into the middle-aged category. Also, they have higher education and usually has worked. This indicates that XYZ users use XYZ e-commerce to make it easier and practical if they go to supermarkets or traditional markets. They are practical people and trust their groceries to XYZ e-commerce. Table 2 shows that level of education and gender have no relationship with satisfaction of using the application. Because any education and gender can access and learn easily, other respondent characteristics have a relationship with satisfaction using the application.

Chiu and Chin (2012) state that access to information about goods is the step to combining the knowledge, so consumers have an attitude toward the goods and services. Ramaj (2015) stated that the share of organisation in the marketplace by integrating technology, procedures and people. The purpose of CRM is consumer retention. Increasing consumer loyalty and profit results in the transformation of strategies and business functions. Consumer satisfaction is the key element for a successful CRM implementation and protection of consumer loyalty.

The result of the structural equation model shows that CRM significantly affects consumer satisfaction, and consumer satisfaction significantly affects consumer loyalty. However, CRM insignificantly affects consumer loyalty. Consumers will feel satisfaction if they get the best CRM. This CRM activity must be taken considering that today's business has turned customer-oriented. CRM activities that have been implemented by XYZ e-commerce are responded to the complaint. In addition to their online platform, XYZ e-commerce has also improved the service using chatbots to optimise CRM. CRM in this study is represented by the dimensions of human resources, processes, technology, and knowledge.

CRM dimensions that should be improved can be seen from the value of the loading factor. The four dimensions, variables of technology and process with an 
average loading value, become the lowest factors. These two dimensions are expected to improve CRM services and consumer satisfaction, leading to consumer loyalty. The indicator that contributes significantly was the company makes it easier to access information. The previous study indicated a different relationship, both positive and significant, between CRM and consumer satisfaction (Rahiminik \& Soheilashamsadini, 2014). This means an improvement of CRM will increase consumer satisfaction. Azzam (2014) also obtained the same research results; namely, CRM affects consumer satisfaction. Therefore, companies should pay much attention to CRM to generate a competitive advantage through consumer satisfaction.

Consumer satisfaction is represented by the dimensions of product quality, service quality, innovation duct, and corporate image (Smith \& Chang, 2010). The power of consumer satisfaction on XYZ e-commerce is the quality of service and product quality seen from the loading factor average. The indicator that contributes significantly was the quality of the product provided is the best. The field findings also showed similar results that the offer products are fresh; most respondents expressed the same thing. Previous studies also concluded a positive and significant relationship between consumer satisfaction and loyalty (Laksmana, Kusuma \& Landra, 2018; Zahro \& Prabawani, 2018). Research conducted by Rizq, Djamaludin, and Nurhadryani (2018) stated that three indicators that can improve consumer satisfaction are ease of handling requirements, speed of services and facilities, and physical condition of office buildings. This result can be input into this research. This means that that the increase of satisfaction will also increase consumer loyalty.

Meanwhile, several studies also showed contradictory that satisfied consumers did not cause an increase in loyalty. However, consumers' ignorance of other companies (Iriandi et al., 2015) and there was no significant consumer satisfaction effect against consumer repurchases associated with consumer loyalty (Simanjuntak, Putri, Yuliati \& Sabri, 2020). Reza, Sumarwan, and Hartoyo (2019) conducted the same research and stated that consumer satisfaction affects consumer loyalty and purchasing behaviour. Besides that, Putra and Yuliati (2016) stated that the study of complaint intention was in the middle category and factors that influenced complaints, namely unsatisfied experience.

CRM did not have a significant direct effect on consumer loyalty. This loyalty change appears due to XYZ's e-commerce promotion recently applied intensively only during a pandemic. According to the respondents, they still feel ordinary and disbelieve in the quality and service of traditional markets. Also, XYZ's e-commerce has not become the top of mind of the respondent. This is supported by the fact that brand resonance and brand loyalty are influenced by generation variables (Olga, David, Dhameeth, Adam \& Elliot, 2018), and the millennial generation quite hard to believe in change. CRM is very effective in supporting consumers' satisfaction to support consumers to make loyal purchases through online shopping. It has a significant effect on consumer satisfaction, and the increase of it can affect loyalty and profit (Dibyo, Mangifera, Putri \& Wardani, 2021; Hassan et al., 2014). Overall, CRM directly affects consumer satisfaction and indirectly affects consumer loyalty through consumer satisfaction. The result shows the importance of CRM in increasing consumer satisfaction and loyalty.

From a theoretical perspective, the results show that CRM significantly directly affects consumer satisfaction and indirectly on consumer loyalty. These results are, in merely put, XYZ e-commerce can increase consumer satisfaction and loyalty by 
improving the CRM. Based on the indicators' contribution, an increase in the human resource dimension was significant in the CRM dimension. The deep priority level improved CRM services sequentially, namely the dimensions of human resources, knowledge, process, and technology. Consumer satisfaction that increased sequentially were service quality, product quality, company image, and product innovation. Each sequential improvement dimension theoretically can increase expected consumer loyalty on XYZ e-commerce.

The managerial implications were divided into marketing mix (4C) and CRM implications on consumer satisfaction and loyalty. First, the marketing mix used as implication managerial is the 4C proposed by Lauterborn (1990). This marketing mix consists of customer needs, customer convenience, customer cost, and customer communication. Customer needs have been met, reflected in the most significant indicator, namely XYZ e-commerce makes it easier to access product information. However, XYZ e-commerce can minimise bugs in the application for consumer convenience. Customer convenience is reflected in the fast service indicator. That was characterised by ease of access to information, easy transactions so that delivery can be done quickly. Customer cost is reflected by the indicator of shopping costs lower than the traditional market, but this is not following the field conditions; namely, the price offered is more expensive. This can be done by product bundling. Customer communication is essential to be taken by the company in the way the company must communicate and provide information to consumers. Companies must involve the consumers, companies should maintain relationships with consumers, and the company must provide solutions. The company can still maximise customer communication to switch to become customers by creating a loyalty program.

The performance improvement of CRM process and technology dimensions had a loading factor value that is still low that will affect the performance of CRM. It needs a strategy for improving the performance of these two dimensions. Process dimension performance improvement can be made with improvements in the ease and fast delivery of goods. Process acceleration delivery of goods could be taken by increasing the stock of products, preparing the right type of transportation in distributing goods, utilising partners stalls that have spread, and implementing a COD (Cash On Delivery) system for collection products. The most important thing is maintaining communication with suppliers to determine how much product or crop can be delivered and scheduled. This strategy must always be monitored and informed to consumers about the certainty of the product they ordered.

Improving the technology dimension performance can be conveyed by changing the user interface appropriately; websites and applications are more user-friendly because there are difficulties in purchasing products using the application. Apart from this, the consumer can complain about errors on the website and application to increase the level of convenience for consumers in accessing the website and applying XYZ ecommerce.

There are several limitations of this study, such as (1) no direct interaction with the respondents that makes researchers unable to dig more in-depth about the reasons for using XYZ e-commerce. The next limitation is (2) There was no determination of the purchase time limit. There may be bias in assessing services, whether prior or after the repair period of XYZ e-commerce services. Finally, (3) the sample's determination using non-probability sampling makes the results only be concluded within the research sample, not generalised at the population level. 


\section{Conclusion}

\section{Conclusion and Recommendation}

Based on the research results, consumer e-commerce XYZ was dominated by females 31 - 40 years old, already married, and have a job with income middle to high. Table 1 shows that level of education and gender have no relationship with satisfaction of using the application. However, because any education and gender can access and learn easily, other respondent characteristics are related to satisfaction using the application.

CRM has a significant effect on consumer satisfaction. Consumer satisfaction also has a significant effect on consumer loyalty. However, CRM has no significant effect on loyalty due to the relatively new start-up. Also, consumers have so many choices that they still like to try and be disloyal to one brand.

A practical managerial implication for the company is to implement the CRM and 4C strategies. Ease in the buying process, professionalism, reliability, and trustworthiness imply that e-commerce can apply PT XYZ. E-commerce needs to improve the relationship between criticism and suggestions, communication and information provision, managing product availability, delivery time, and saving consumer costs. This is also can be seen from the weaknesses, opportunities and threats of the company. Overall, the improvement of e-commerce services need awareness of increasing the desired value, improving product quality, and the ease of access to information that will lead to consumer loyalty.

\section{Recommendation}

Suggestions for future research can add other research variables such as brand awareness, customer retention, and customer engagement. The purpose of this addition is to analyze the various factors that can develop the company. These research purposes recommend e-commerce XYZ to maintain and increase the easiness of purchasing process, professionalism, reliability, and trustworthiness. In addition, this field needs to improve the relationship between criticism and suggestions, communication and information provision, managing product availability, delivery time, and saving consumer costs. Next, needs also improve consumers' desired value, product quality, and ease of access to information, such as the product's availability, besides that, to analyze segmentation strategy that can affect not just women but also men. 


\section{References}

[BPS] Badan Pusat Statistik. (2020). Results of the Social Demographic Impact of COVID-19 Survey. Jakarta(ID): BPS. Retrieved from https://www.bps.go.id/publication/2020/06/01/669cb2e8646787e52dd171c4/hasilsurvei-social-demographics-impact-covid-19-2020.html.

Azzam, Z. A. M. (2014). The impact of customer relationship management on consumer satisfaction in the banking industry - a case of Jordan. European Journal of Business and Management, 6(32), 99-112. ISSN: 2222-2839.

Brenski, W. (2015). Customer centricity and satisfaction as a key aspect of CRM. Problems and Perspective in Management, 13(1), 176 - 184.

Buttle, F. (2007). Customer Relationship Management: Concept and Tools. Malang (ID): Bayu Media Publishing.

Chiu, C. C., \& Chiu, T. S. (2012). The effect of product attribute new information on consumer elaboration and brand attitude. The Journal of International Management Studies, 7(1), 168-176. E-ISSN: 2378-9557.

Darvish, H., Kafashzadeh, A. R., \& Ahmadnia, H. (2012). Studying the customer relationship management: a case study at Persian technology firm petroleum gas. University of Ploiesti Bulletin, Technical Series, 62(2), 1-18.

Dawes, J. (2009). The effects of service price increases on customer retention: the moderating role of customer tenure and relationship bread. Journal of Services Research, 11(3), 232-247. Doi: 10.1177/1094670508328986.

Dewa, B. P., \& Seyohadi, D. B. (2017). Analysis of the impact of customer relationship management factors in seeing satisfaction and loyalty levels on marketplace customers in Indonesia. Telematika, 14(1), 33-38. Doi: https://doi.org/10.31315/telematika.v14i01.1964

Dibyo, B., Mangifera L., Putri P. A. K., \& Wardani S. F. A. (2021). Inclusive Growth in Developing Countries, 2(1), 31-40.

Emaluta, F.H.K., Isnalita, I., \& Soewarno, I. (2019). The effect of customers' satisfaction as mediator variables. Jurnal Akuntansi dan Sistem Informasi, 4(2), 59 -63.Doi: https://doi.org/10.32486/aksi.v4i2.352

Engel, J. F., Blackwell, R. D., \& Miniard, P. (1994). Consumer Behavior Volume 1. Jakarta (ID): Bina Rupa Script.

Ghazian, A., Hossaini, M. H., \& Farsijani, H. (2016). The effect of customer relationship management and its significant relationship by customer reaction in LG Company. Procedia Economics and Finance, 36, 42-50. Doi: 10.1016/S22125671(16)30014-4

Gordon, I. (2002). Best practices: customer relationship management. Ivey Business Journal, 3(2), 1-6.

Griffin, J. (2003). Consumer loyalty: Growing and Maintaining Consumer loyalty. Jakarta (ID): Erlangga.

Hair, J. F., Black, W. C., Babin, B. J., \& Anderson, R.E. (2010). Multivariate Data Analysis: A Global Perspective (7th Edition.). New Jersey(US): Pearson Education. Inc.

Hassan, R. S., Nawaz A., Lashari, M. N., \& Zafar, F. (2014). Effect of Customer Relationship Management On Customer Satisfaction. Procedia Economics and Finance, 23, 563-567. Doi: 10.1016/S2212-5671(15)00513-4. 
Iriandi, A. P., Yulianto, E., \& Mawardi, M. K. (2015). The influence of customer relationship management on consumer satisfaction and loyalty. Journal of Business Administration, 23(2), 1-8.

Khedkar, E. B. (2015). Effect of customer relationship management on consumer satisfaction and loyalty. Journal Impact Factor. 6(5), 01-07. ISSN: 0976-6510.

Kotler, P., \& Keller, L. K. (2016). Marketing Management (15th Global Edition). New Jersey(US): Pearson: Prentice-Hall.

Laksmana, I. N. H., Kusuma, I. E. T., \& Landra, I. N. (2018). Effect of customer relationship management on consumer satisfaction and loyalty at PT Harmon Permata Gianyar. Bali. International Journal of Contemporary Research and Review, 9(3), 20610-20617. Doi: https://doi.org/10.15520/ijcrr/2018/9/03/470

Lauterborn, B. (1990). New marketing litany: four ps passe: C-words take over. Advertising Age, 6(41), 26.

Lestari, Y. T., \& Suwitho. (2018). The influence of customer relationship management on customer loyalty. Journal of Management Science and Research, 7(1), 17-26.

Olga, B., David, D. D., Dhameeth, G. S., Adam, S., \& Elliot, S. (2018). The millennials: insights to brand behavior for brand management strategies. Journal of Management and Strategy, 9(3). Doi: https://doi.org/10.5430/jms.v9n3p1

Putra, R. P., \& Yuliati, L. N. (2016). The effect of unsatisfied, culture value, and value loss on complaints intention of electronic devices in Bogor, West Java, Indonesia. Journal of Consumer Sciences, 1(1), 47-58. Doi: https://doi.org/10.29244/jcs.1.1.47-58

Rahayu, E., Kifti, W. M., Informasi, S., Royal, S. (2018). Customer relationship management on customer satisfaction and its impact on customer loyalty PT Bank Rakyat Indonesia. Journal of Management and Innovation, 8(2), 70-83.

Rahiminik, A., \& Soheilashamsadini. (2014). The relationship between customer relationship management and consumer satisfaction with the expected value of the consumer audio and video products Samsung in Kerman. International Journal of Management Sciences and Business Research, 3(7), 31-47. ISSN: 2226-8235.

Ramaj, A. (2015). Customer relationship management, customer satisfaction and loyalty. Academic Journal of Interdisciplinary Studies, 4(3), 594 - 599. Doi:10.5901/ajis.2015.v4n3s1p594.

Reza, F., Sumarwan U., \& Hartoyo. (2019). Satisfaction, purchasing behaviour and customer loyalty of butik emas logam mulia. Journal of Consumers Sciences, 4(2), 90-107. Doi: https://doi.org/10.29244/jcs.4.2.90-107

Rizq, S., Djamaludin, M. D., \& Nurhadryani, Y. (2018). Analysis of service quality satisfaction of e-KTP service at public administration and civil registration Office of Bogor district. Journal of Consumer Sciences, 3(2), 55-65. Doi: https://doi.org/10.29244/jcs.3.2.55-65

Setyaleksana, B. Y., Suharyono, \& Yulianto, E. (2017). The influence of customer relationship management (CRM) on consumer satisfaction and loyalty. Journal of Business Administration (JAB), 46(1), 45-51.

Simanjuntak, M., Putri, N. E., Yuliati, L. N., \& Sabri, M. F. (2020). Enhancing customer retention using customer relationship management approach in car loan business. Cogent Business and Management, 7(1), 1-17. Doi: https://doi.org/10.1080/23311975.2020.1738200 
Smith M., \& Chang. (2010). Improving customer outcomes through the implementation of customer relationship management evidence from Taiwan. Asian Review of Accounting, 18(3), 260-285. Doi: http://dx.doi.org/10.1108/13217341011089658

Soegoto, A. S. (2013). Persepsi nilai dan kepercayaan terhadap kepuasan dan dampaknya terhadap loyalitas konsumen. Emba's Journal, 1(3), 1271-1283. Doi: https://doi.org/10.35794/emba.1.3.2013.2548

Soliman, H. S. (2011). Customer relationship management and its relationship to the marketing performance. International Journal of Business and Social Science, 2(10), 166-182.

Sumarwan, U., Hartoyo, \& Fahmi, I. (2018). Business and Consumer Research Methods. Bogor (ID): IPB Press.

Supar, D. A. W. A., \& Suasana, I. G. A. ketut G. (2017). The role of customer satisfaction in mediating the influence of customer relationship management on customer loyalty. E-Jurnal Manajemen Unud, 6(3), 1564-1591. E-ISSN: 23028912.

Vasiliu, D. (2012). Approach to customer relationship (CRM) - the new key sales success. USV Annals of Economics \& Public Administration, 12(1), 144-153.

Victor, C., Rotinsulu, J. P., Jacky, S. B., \& Sumarauw. (2015). The influence of customer relationship management and trust in satisfaction and its impact on consumer loyalty. EMBA Journal Sam Ratulangi University Manado, 3(2), 671683. ISSN: 2303-1174.

Yuliana, Y. (2018). Efforts to build consumer loyalty through a qualitative approach to product quality and service quality at the economics faculty of UMN Al Washliyah Medan T.A 2013/2014. Journal of Humanities Social Education Research, 2(2), 282-289. Doi: https://doi.org/10.32696/jp2sh.v2i2.68

Zahro, N. U., \& Prabawani, B. (2018). The influence of customer relationship management on loyalty cable tv customers in Tembalang sub-district through consumer satisfaction as a variable intervening (study at PT MNC sky vision Indovision Semarang). Journal of Business Administration, 7(1): 10-18. 